\title{
THE RETRANSLATION OF WALLACE STEVENS' "OF MERE BEING"
}

\author{
Paulo Henriques Britto ${ }^{1 \times}$ \\ ${ }^{1}$ PUC-Rio, Rio de Janeiro, Rio de Janeiro, Brasil
}

Abstract:

An analysis of the 2017 retranslation into Brazilian Portuguese of a poem by Wallace Stevens originally translated in 1987, with a detailed contrastive study of the two versions of the poem's last line, which had been inadequately translated in 1987.

Keywords: Poetry Translation; Wallace Stevens; Retranslation

\footnotetext{
* É tradutor e professor de tradução, criação literária e literatura no Departamento de Letras da PUC-Rio, nos níveis de graduação e pós-graduação, no programa de Estudos da Linguagem e no de Literatura, Cultura e Contemporaneidade. É autor de dez livros (poesia, ficção e ensaio). Como tradutor, é responsável por mais de 110 livros publicados, em sua maioria obras de ficção, mas também de poesia e não-ficção. phbritto@hotmail. com. ORCID: 0000-0002-8979-2424.
} 


\section{OF MERE BEING}

The palm at the end of the mind, Beyond the last thought, rises

In the bronze decor,

A gold-feathered bird

Sings in the palm, without human meaning,

Without human feeling, a foreign song.

You know then that it is not the reason

That makes us happy or unhappy.

The bird sings. Its feathers shine.

The palm stands on the edge of space.

The wind moves slowly in the branches.

The bird's fire-fangled feathers dangle down.

Upon reading two poems by Wallace Stevens for the first time- "Domination of Black" and "Sea Surface Full of Clouds"-I was so impressed that I immediately began to translate them. A few years later, Luís Schwarz founded Companhia das Letras and I began to work for the new publishing house; when Schwarz found out I was translating some poems by Stevens, he told me he would be interested in publishing an anthology. So what till then had been a labor of love turned into a professional assignment. In less than a year I translated the other poems that were eventually included in the anthology and wrote a short introduction, on the basis of the few works about Stevens to which I had access at the time. The book came out in 1987, and in a few years it went out of print. By then I had become considerably more knowledgeable about versification and poetry translation, and it began to seem to me that many of my versions of Stevens's poems were quite unsatisfactory. For this reason, I asked Companhia das Letras not to reprint the 1987 anthology, and decided that someday I would prepare an expanded, revised version. As it turned out, this came to happen only thirty years later.

The problems I found in my translations were of various kinds. The ones that troubled me least were those of the most obvious kinds, involving typos, misreadings and bad proofreading; these were relatively easy to correct. A more serious problem was what might be described as a sort of hypercorrection. Every translator of poetry must be constantly aware of the danger of sticking so closely to the literal sense of the lines that the formal features of the poem are neglected. In the case of Stevens, particularly early Stevens, in Harmonium, the music of the lines-the rhythm, the play of vowel and consonant sounds-matters at least as much as what is actually being said, and occasionally more. But in my translation of "Domination of Black," the very first Stevens poem I ever read, one of my most egregious mistakes was of exactly the opposite kind: excessive concern with formal properties of the poem 
made me ignore the semantic aspect to the point of absurdity. The poem evokes a hallucinatory night scene in which two sensorial elements are emphasized at several points: "the color of the heavy hemlocks," a visual detail, and "the cry of the peacocks," a sound. "Hemlock," of course, means both a kind of pine tree and the poison that killed Socrates; this duality of meanings could not possibly be recreated in Portuguese, something I did not even try to do. But "hemlock" also rhymes with "peacock," and this rhyme is crucial in the poem, being repeated at the end of each stanza. I was so taken with the problem of finding a rhyme for the Portuguese word "pavões" ("peacocks") that I translated hemlocks as "açafrões" ("saffron flowers"), a plant the color of which could not be more different from the black that dominates the poem. In my revised version, I opted for "pinhões" ("pine seeds"), which is semantically close to the most relevant meaning of "hemlock" in the poem and is associated with a dark color.

However, most of the changes I made for the new edition of the anthology had more to do with form than with meaning. Back in the 1980s, I was still beginning to learn about poetic form in English and Portuguese. For this reason, particularly when dealing with the longer poems of Stevens' second phase, I often came up with unmusical lines that did not follow any regular metrical pattern, even though in most of Stevens's poems there is what T.S. Eliot calls a "ghost meter": a regular metrical pattern that is evoked rather than closely followed by the actual lines. Revising the 1987 translations thirty years later, I was able to find solutions that were metrically regular for many passages without straying too far from the literal meaning of the original lines. Here, for instance, is a passage from section V of "The Man with the Blue Guitar," in the original, in my first translation and in the revised version:

Day is desire and night is sleep.

There are no shadows anywhere.

The earth, for us, is flat and bare. There are no shadows. Poetry

Exceeding music must take the place Of empty heaven and its hymns,
Dia é desejo e noite é sono. Não há sombras em lugar nenhum.

Pra nós, a terra é plana e nua. Não há sombras. A poesia

Mais do que a música há de ocupar $O$ vazio de um céu sem hinos;
Dia é desejo e noite é sono.

Sombras não há em parte alguma.

Pra nós, a terra é plana e nua.

Sombras não há. A poesia

Mais do que a música, há de ocupar $O$ céu vazio sem salmodias;

Throughout this long poem, Stevens uses regular iambic tetrameters. In my first version I was unable to adhere to a regular meter: in the first distich, the second line has nine syllables; in the second, the second line has seven or eight syllables, but the distribution of accents in pretty haphazard; and in the third, the second line is a heptasyllable. In the revised version, in each distich the second line has been modified so as to follow some regular octosyllabic pattern: 1-4-6-8, 1-4-8 e 2-4-8, respectively (the numbers indicate stressed syllables). I also managed to introduce a partial rhyme between "poesia" and "salmodias" that connected the second distich to the third, so as to compensate 
for the loss of the full rhyme between "anywhere" and "bare" connecting the first and the second distichs.

Let us now turn to what is usually considered Stevens' very last poem, which is also one of his masterpieces - "Of Mere Being" - and the problems it presents to translation. Legget (2007: 74) observes that this poem "sets itself the paradoxical task of describing a state of being that exists apart from human intelligence and feeling." He observes that the golden bird in the poem is reminiscent of the one mentioned in Yeats's "Sailing to Byzantium," which in turn probably derives from Hans Christian Andersen's story “The Nightingale." In Andersen's tale, the Emperor of China replaces an actual living nightingale with a gem-studded mechanical bird; when the mechanism of the artificial bird goes awry and the Emperor seems close to death, the flesh-and-blood nightingale comes back and sings the emperor back to health. In Yeats's poem, however, it is art and artifice that have the last word, rather than nature and the organic: the poem's speaker, an old man who disparages his own decaying body, travels to Byzantium, a city conceived as a place where everything is artificial, in order to find a bird made of gold and enamel, which, not being a part of nature, is immortal.

In Stevens's poem, the setting is also marked by artificiality: a "palm at the end of the mind" in "a bronze decor". "The bird has gold feathers, and his song is a "foreign song," devoid of "human meaning" and "human feeling." But the poem's theme is not the superiority of the artificial in relation to the natural; the third stanza states the central idea of the poem: reason is not what "makes us happy or unhappy." This raises the obvious question: if not reason, then what? The next stanza, the last one, provides no answers; it simply describes the palm, the wind and the bird, and ends with what it would not be excessive, I think, to qualify as one of the most magnificent lines in all of English poetry.

Rhythmically, "Of Mere Being" is characterized by extensive metrical variation in only a dozen lines, as Cook (2007: 314) observes. The scansion proposed below should be taken with a grain of salt, as is always the case when dealing with poems without a well-defined metrical contract; but I believe it is still worth a look. ${ }^{2}$

\begin{tabular}{|c|c|}
\hline $\begin{array}{l}\text { The palm at the end of the mind, } \\
\text { Beyond the last thought, rises } \\
\text { In the bronze decor, }\end{array}$ & $\begin{array}{l}-/|--/|--/ \| \\
-/|-/| / \| / \mid- \\
--/|| /||\end{array}$ \\
\hline $\begin{array}{l}\text { A gold-feathered bird } \\
\text { Sings in the palm, without human meaning, } \\
\text { Without human feeling, a foreign song. }\end{array}$ & $\begin{array}{l}-/|/-| / \mid \\
-1-|-/||-/| /-\mid /- \\
-/|/-| /-||-/ \mid-1\end{array}$ \\
\hline $\begin{array}{l}\text { You know then that it is not the reason } \\
\text { That makes us happy or unhappy. } \\
\text { The bird sings. Its feathers shine. }\end{array}$ & $\begin{array}{l}-/|/|--|-/|-/ \mid- \\
-/|-/|--|| /|-| \mid \\
-/|/||-/|-/ \|\end{array}$ \\
\hline $\begin{array}{l}\text { The palm stands on the edge of space. } \\
\text { The wind moves slowly in the branches. } \\
\text { The bird's fire-fangled feathers dangle dowr }\end{array}$ & $\begin{array}{l}-/|/-|-/|-/| \mid \\
-/|/||--|-/|-| \mid \\
-/|/ /|-/|-/|-/ \mid\end{array}$ \\
\hline
\end{tabular}


The first stanza is in free verse, with enjambment between lines 2 and 3. Though the division in feet presented above may be questioned, it seems clear that there are three stresses in each acoustic line-that is, the line considered as a speech unit and a syntactic unit, ending on some sort of pause, as opposed to the graphic line, the line as it appears on the page, which may be end-stopped or enjambed, contain any number of pauses and include more than one syntactic unit. The first acoustic line coincides with the first graphic line, but the second acoustic line ends on "thought"; the third one begins with "rises" and continues up to the end of the stanza. This division of the stanza into acoustic lines, determined by pauses, is reinforced by the assonance between the stressed syllables in "thought" and "décor," which functions as a near-rhyme between the acoustic lines:

l 1

The palm at the end of the mind,

l 1 /

Beyond the last thought,

l l I I

rises In the bronze decor,

The second stanza seems more amenable to traditional scansion, though iambic and trochaic feet are combined in an unconventional way. The enjambment and the comma on the third line allow us to divide the stanza into four acoustic lines, but the count of stresses per acoustic line is irregular: five on the first, three on the second and on the third - two almost identical acoustic lines-and two on the fourth.

A gold-feathered bird Sings in the palm,

l 1 /

without human meaning,

/ 1

Without human feeling,

l 1

a foreign song.

The third stanza, like the first, is not readily analyzable into regular feet. The first and second graphic lines are enjambed and do not present a well-defined metrical pattern, while the third may be divided in two acoustic lines, each containing two stresses.

$$
\text { / } 1
$$

The bird sings.

/ 1

Its feathers shine. 
The fourth stanza is the most regular of all. Here each graphic line corresponds to an acoustic line and to a complete sentence. Lines 1 and 2 have four feet and four stresses each:

$$
\text { l } 111
$$

The palm stands on the edge of space.

$$
\text { l } 1 \text { 1 I }
$$

The wind moves slowly in the branches.

The final line will be discussed in greater detail later. Let us now examine the repetition of words, phrases, vowel and consonant sounds in the poem.

The palm at the end of the mind,

Beyond the last thought, rises

In the bronze decor,

A gold-feathered bird

Sing-gs in the palm, withoụt hụmaṇn meanịng,

Without humman feeling, a foreign șong.

You know then that it is not the reason

That makes us happy or unhappy.

The bird sings. Its feathers shine.

The palm stands on the edge of space.

The wind moves slowly in the branches.

The bird's fire-fangled feathers dangle down.

Occurrences of assonance and alliteration are relatively few, but there is much repetition of words and phrases. The nouns "palm," "bird" and "feather(s)" (and also "feathered") appear two or three times each; the verb "sing" and the noun "song" may also be counted as an instance of repetition, and the same treatment may be given to the pair "happy"/ "unhappy." In the second stanza, as has been mentioned, an acoustic line is repeated almost identically, save for one syllable, establishing the opposition between "meaning" and "feeling," both terms being negated by "without." There are also two phrases with negative meaning occurring in the first stanza: "The end of the mind" and "Beyond the last thought." A final negation comes at the beginning of the third stanza: "it is not the reason That makes us happy or unhappy." The bird on the palm tree is placed in an artificial context beyond human reason and also beyond human feeling. Mere being, then, is being without thinking and without feeling, outside the sphere of consciousness. The final stanza specifies that the palm mentioned on the opening line is "on the edge of space": that is, between space and whatever it is that lies outside space. Although the setting of the poem is clearly artificial, the next-to- 
last line mentions that a wind is blowing. And so we arrive at the splendid closing line: "The bird's fire-fangled feathers dangle down."

The subject of the sentence that makes up the final line contains a neologism. According to Cook (2007: 314), "fire-fangled" combines "fire-fanged," which means "caught by fire, singed, scorched," and "newfangled," so that two meanings are involved: "burned' and 'inclined to take fire." The meaning of "dangle" is intensified by "down." The resulting image is that of a bird touched by fire in some way, resting on the branch of a tree, its feathers swinging lightly, perhaps indicating that at any moment it might take flight again.

As regards assonance, alliteration, rhyme and meter, this line is extraordinarily rich:

$-1|1| 1|-1|-1 \mid-1$

The bird's fire-fangled feathers dangle down.

No fewer than six consonants alliterate here: /r/, /f/, /y/,/g/, /l/ and /d/; there is internal rhyme between fangled and dangle, in fact a full rhyme because the initial /d/ in down follows the second syllable of dangle. The three occurrences of the fricative /f/ in stressed syllables evokes the flapping of the bird's wings, a movement interrupted by the double occurrence of the stop /d/ and the final pause. Metrically, the line is the most regular in the entire poem: iambic pentameter with spondaic substitution in the second position, so that three successive primary stresses occur on the second, third and fourth syllables of the line, just as on the previous line ("wind moves slow-").

My original translation of this line was one of the most infelicitous passages in the anthology:

As penas de fogo do pássaro pendem frouxas.

Here there was an attempt to partly recreate the repetitions of phonemes in the original, with the internal off-rhymes penas-pendem and fogo-frouxas. But the meaning of the line-which may be translated back into English roughly as "the bird's fire feathers droop loosely" - conveys the idea of a badly made artificial bird, with feathers liable to drop off at any moment. For reasons of space, I will not go into a comparison of the two versions of the poem, but will simply present the 2017 version and concentrate on the original and the revised versions of the final line. 


\begin{tabular}{|c|c|c|}
\hline IERAMENTE SER & & \\
\hline $\begin{array}{l}\text { A palmeira no final da mente, } \\
\text { Alé̉ do pensamento último, se eleva } \\
\text { No brônzeo cenắrio, }\end{array}$ & $\begin{array}{l}-1--1-1-\| \\
-1--1-1--\|-1- \\
-1--1-\|\end{array}$ & $\begin{array}{l}3-7-9 \\
2-6-8-12 \\
2-5\end{array}$ \\
\hline 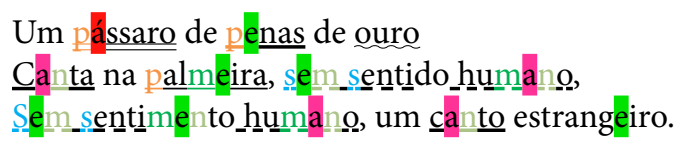 & $\begin{array}{l}-1--1--1- \\
|---|-\|/-I-1-\| \\
I--I-/\|-I--I-\|\end{array}$ & $\begin{array}{l}2-6-9 \\
1-5-7-9-11 \\
1-4-6-8-11\end{array}$ \\
\hline $\begin{array}{l}\text { Entẫo você entende que não é a razẫo } \\
\text { Que nos traz tristeza ou alegria. } \\
\mathrm{O} \text { pássaro canta. As penas brilham. }\end{array}$ & $\begin{array}{l}-1--1 \mid-1-1-\| \\
-1-1-1--1-1 \\
--1-1--1-\|\end{array}$ & $\begin{array}{l}2-4-6-10-12 \\
3-5-9 \\
2-5-7-9\end{array}$ \\
\hline $\begin{array}{l}\text { A palmeira paira no limiăr do espaço. } \\
\text { O vento roça devagâr seus gallhos. } \\
\text { As penas de ouro do pássaro resplendem fogo. }\end{array}$ & $\begin{array}{l}--1-1--1-1-1-\| \\
-1-1--1-1-\| \\
-1--1--1--1-1-\|\end{array}$ & $\begin{array}{l}3-5-(8)-10-12 \\
2-4-8-10 \\
2-5-8-12-14\end{array}$ \\
\hline
\end{tabular}

On the formal plane, the most obvious difference between original and translation is the greater occurrence of alliteration and assonance in the translation. In the final stanza, the alliterations in $/ \mathrm{p} / \mathrm{e} / \mathrm{g} /$ and the assonances in /e/, /a/ and /o/ are particularly conspicuous.

Another major difference has to do with the fact that the lines are longer in the translation than in the original, but this is inevitable in any translation from English to Portuguese.

It has been mentioned that in Stevens' poem there is great metrical variety. My scansion showed that the poem tends to become metrically more regular as it develops, so that the final line is the most regular of all. In my new translation, lines vary in length from 5 to 14 syllables, but some of them are metrically regular: there are three twelve-syllable lines (stanza 2, line 2; stanza 3, line 1; stanza 4, line 1), and one so-called Sapphic decasyllable (stanza 4, line 2).

The fourth stanza is the one that has the most instances of alliteration and assonance. This concentration of phonological effects is an attempt to compensate for my inability to do full justice to the final line. The metrical regularity of the original was lost: the iambic pentameter was recast as a quite irregular 14-syllable line. The lexical strangeness of "fire-fangled" was recreated as the syntactic oddity of "resplendem fogo." It will be noted that the word ouro reappears on the final line even though "gold" is not repeated in the original; this was a way to achieve assonance with the vowel in fogo; the final effect was the vowel sequence /e/-/o//a/-/e/-/o/, with three occurrences of /p/.

Semantically, the changes on the final line are quite radical. In Stevens' original text, we have the repetition of /f/ evoking the flapping of wings, followed by an indication that the wings are now at rest, dangling down: the emphasis is on movement and stillness. None of this has been recreated in the translation. No attempt was made to reproduce the contrast between movement and stillness; instead, the translation focuses on the brightness of the wings, compared with both fire and gold. This change was brought about by the fact that "dangle" 
has no Portuguese equivalent; indeed, English has a large number of verbs of movement that cannot be translated into Portuguese except by awkward and lengthy paraphrases. My intention was to concentrate on the sound texture of the original, and to attempt to reproduce at least part of it. My new version is clearly an improvement on the 1987 translation, but just as clearly it is no match for the English original.

But this statement should not be taken to mean that I subscribe to the notion, held by many literary translators, that all translations are fated to be inferior to the originals they attempt to recreate. Indeed, I think it would be fair to say that at least some of the translations in my Stevens anthology give the reader a pretty adequate view of the original poems. And I will go as far as to claim that now and then a brilliant translator may even improve on the original: such is the case, I believe, of Fernando Pessoa's take on Edgar Allan Poe's "The Raven."3 But as regards my translation of Stevens' "Of Mere Being," with its masterful closing line, it would be absurdly presumptuous to say that my translation is about as good as the original. All I can say is, I have done my best - and hope that someone else will find a better solution someday. For when a translator says that a given line of verse is untranslatable, what he really means is that he was unable to find a satisfactory solution for it. Other translators may do better.

Notes

1. For my first translation, I had used the 1966 edition of Opus posthumous, where the phrase that occurred was "bronze distance"; this was corrected in subsequent editions of Stevens's poetry.

2. The symbols used in scansions in this article are: -, unstressed syllable; /, primary accent; \, secondary accent; |, foot separator; ||, pause.

3. On this, see Britto 2019.

\section{References}

BRITTO, Paulo Henriques. "Um raven e dois corvos". In POE, Edgar A. O corvo. São Paulo: Companhia das Letras, 2019.

COOK, Eleanor. A Reader's Guide to Wallace Stevens. Princeton e Oxford: Princeton University Press, 2007.

LEGGETT, B. J. "Steven's late poetry". In SERIO, John N. (org). The Cambridge Companion to Wallace Stevens. New York: Cambridge University Press, 2007, p. 62-75.

STEVENS, Wallace. Poemas. Translated and with an introduction by STEVENS, Wallace. Poemas. Translated and with an introduction by Paulo Henriques Britto. São Paulo: Companhia das Letras, 1987.

Collected poetry and prose. New York: Library of America, 1997.

O imperador do sorvete e outros poemas. Translated and with an introduction by Paulo Henriques Britto. São Paulo: Companhia das Letras, 2017. 